\title{
Investigation of the Effect of Perceived Risk Factors on Online Shopping
}

\author{
Ozlem Sen \\ Antalya AKEV University, Department of Gastronomy and Culinary Arts, \\ Belek / Antalya / Turkey \\ E-mail: ozlem.sen@akev.edu.tr
}

\begin{abstract}
The aim of this study is to analyze the factors affecting the consumers' online shopping behavior. Online shopping behavior is a complex process that involves too many factors. Studies on the subject are still insufficient compared to traditional consumer behavior. One of the aims of this study was to cover the shortcomings of previous studies that did not examine the main factors affecting online shopping behavior. This objective was followed using a model that examines the impact of perceived risks, infrastructure variables and return policy on the attitudes towards online shopping behavior.

The study determined that financial and productive risks, compliance risk, return policies and delivery risk have an adverse effect on the attitude towards online shopping.
\end{abstract}

Key Words: Online Shopping, Online Consumer, Consumer Behavior

DOI: $10.7176 / J S T R / 5-8-02$

\section{Online Alışverişte Algılanan Risk Faktörlerinin Alışverişe Yönelik Tutuma Etkisinin İncelenmesi}

\begin{abstract}
Özet
$\mathrm{Bu}$ çalışmanın amacı, tüketicilerin çevrimiçi alışverişe yönelik tutumu etkileyen risk faktörlerinin tutum üzerindeki etkisini analiz etmek ve online tüketicilerin alışveriş davranışları, tercihleri ve gelir-cinsiyete göre değişikliklerini belirlemektir. Online alışveriş davranışı, karmaşık ve çok fazla faktör içeren bir süreçtir. Konuyla ilgili yapılan çalışmalar geleneksel tüketici davranışına kıyasla hala yetersizdir. Bu çalışmanın amaçlarından biri, online alışveriş davranışını etkileyen ana faktörleri incelemeyen önceki çalışmaların eksikliklerini kapsamaktır. Bu hedef, algılanan risklerin, alt yapı değişkenlerinin ve iade politikasının, online alışveriş davranışına yönelik tutum üzerindeki etkisini inceleyen bir model kullanılarak takip edilmiştir.

Çalışma, finansal ve ürünsel risklerin, uygunluk riskinin, iade politikalarının ve teslimat riskin online alışverişe yönelik tutumu olumsuz yönde etkilediğini belirlemiştir.
\end{abstract}

Anahtar Kelimeler: Çevrimiçi Alışveriş, Çevrimiçi Tüketici, Tüketici Davranışı

\section{Giriş}

İnternet üzerinden alışverişin tüketicilerin davranışları üzerindeki etkisi her geçen gün hızla artmaktadır. $\mathrm{Bu}$ artış, alışveriş siteleri üzerinden aradıkları her türlü ürüne veya hizmete ulaşılabilmesi, söz konusu ürün ve hizmetler hakkında detaylı olarak bilgi edinebilmesi, fiyat ve ürünlere ait diğer tüketicilerin yorumlarının karşılaştırması yapılabilmesi gibi olanaklara bağlıdır. İnternetin günlük hayata girmesi, hatta günlük hayatın vazgeçilmez bir parçası olması, online perakendeci firmalara da, daha geniş 
pazarlara ulaşma, tüketicilerin kişisel tercih, ihtiyaç ve taleplerine uygun olabilecek çeşitli ürün, hizmet ve fikirleri, çoğu zaman daha az maliyet ve daha az zamanda tedarik edebilme gibi kolaylıklar da sağlamaktadır. Online tüketici sayısındaki artısıı, son zamanlarda internet kullanıcılarının sayısındaki artıştan daha fazla olduğu görülmekte ve bu da, daha fazla kullanıcının internet üzerinden alş̧veriş yapmaya eğilimli olduğunu göstermektedir. Bu artış, yalnızca online tüketicilerin sayısında değil, bu artş̧a paralel olarak internetten yaptıkları alışverişin hacmine de yansımaktadır (Algür ve Cengiz, 2011). Geleneksel yöntemle yapılan alışverişe alternative bir yöntem olan online alışveriş, tüketicilerin yaşam standartları ve yaşam stillerinin değişmesi ve zaman kısıtı gibi etkenlerle, gelişmiş ülkelerde olduğu gibi ülkemizde de giderek yaygınlaşmıştır. Sanal mağazaların sayısı gün geçtikçe artmakta ve tüketicilere geniş yelpazede seçenekler sunmaktadırlar (Turan, 2008).

İnternet ortamı, fiziksel ortamın aksine tüketicinin tam anlamıyla özgür olduğu alandır. Sıradan mağazalarda karşılaşılan davranış normları, internet ortamında geçerli değildir. İnternet, alışveriş ortamını olabildiğince kişiselleştirmiştir. Alışveriş yapmak için fiziksel bir çaba sarf edilmediğinden çok sayıda web sitesi kısa zamanda gezilebilir. İnternet ortamında satın alma davranışını etkileyen en önemli faktörler seçeneklerin bolluğu ve güvenlik konusudur. İnternet, kendi tüketici profilini yaratmaktadır ve buna göre internet tüketicisi, geleneksel ortamdan farklı olarak satın alma süreçlerini kontrol eden, bilgili, bilinçli ve aşırı derecede talepkardır (Kırcaova, 2012:118).

Her ne kadar internet tüketicisi ve geleneksel tüketici davranışları arasında farklılıklar gösteren çalışmalar olsa da, farklı çalışmalar ve sonuçlar da söz konusudur. Bir başka çalışma, geleneksel tüketicilerin ve internetten satın alanların, birçok ortak özelliğe sahip olduğunu göstermektedir. Tüketicilerin sosyal etkileşimle hareket istemesi ve satın alma faaliyetini sadece faydacı şekilde değerlendirmemesi nedeniyle gerçekleştirmeleri ortak özellikler arasındadır (Denis vd., 2009).

İnternetten alş̧veriş yapan tüketicilerin önceki deneyimleri, interneti kullanım düzeyleri ve içinde bulundukları koşullar internetten satın alma davranışı gösterme potansiyellerini etkilemektedir (Forsythe ve Shi, 2003).

Yapılan çalı̧̧malar, internet tüketicilerinin çeşitli kolaylıklar elde edebileceklerini ifade etmektedir. Farklı çalıșmalarda ortaya konan bu kolaylıklar; alıșveriș için ayrılan zamanın azalması, alıșveriș zamanında esneklik, mağazaları ziyaret etmeyle kullanılacak olan fiziksel çabanın en aza inmesi, kötü hissettirecek durumlarla karşılaşma riskinin ortadan kalkması, müşteri memnuniyetini arttırıcı uygulamalar, seçenek fazlalı̆̆ı, taksitlendirmede sunulan imkan çeşitliliği ve herhangi bir reklam faaliyetine tepki verecek şekilde plansız şekilde satın alma olanağıdır (Donthu ve Garcia, 1999), (Ayden ve Demir, 2014).

\section{Teorik Altyapı ve Literatür}

Tüketiciler; gerek geleneksel gerek online pazarlarda, sürekli bir uyaran akışı altındadırlar. Bunun için, pazarlamacılar sürekli olarak tüketicileri ve tüketicilerin kararlarını nasıl verdiklerini anlamaya çalışmaktadırlar (Hollensen, 2004). Pazarlamacılar, tüketicilere iletilecek olan çıktıyı, ancak tüketiciye gönderilirken kontrol etme ve karar verme olanağına sahiptir, ama bir reklam, tüketiciye ulaştı̆̆ı anda kontrol sona ermektedir. Tüketici, daha sonra, bilgileri kendi yorumlamaktadır ve bu yorumlama da her tüketici için kendine özgü faktörlere dayanmaktadır.

İnternet, mal ve hizmet alışverişi için geniş bir küresel pazar haline geldi. Tüketiciler, bankacıllık işlemleri, fiyat araştırması, ürün araştırması, mal ve hizmet satın alma birçok sebep için interneti kullanmaktadır. İnternetin, geniş ürün yelpazesi ve 24 saat ulaşlabilir olmasıyla, e-ticareti, ticari işlemlerde vazgeçilmez bir pazarlama kanalı haline gelmiştir. Online mağazalar ve hizmet sağlayıcılar, tüketiciler için önemli satış kanallarıdır.

Online alışveriş davranışı, internet üzerinden ürün veya hizmet satın alma sürecini ifade eder. Süreç, geleneksel alışveriş davranışlarıyla ilişkili olanlara benzer beş adımdan oluşmaktadır (Liang ve Lai, 2000). Tipik online alışveriş sürecinde, potansiyel tüketiciler bazı ürünlere veya hizmetlere ihtiyaç duyduklarında internette aramaya giderler.

Bununla birlikte, aktif olarak arama yapmaktan ziyade, potansiyel tüketiciler, ihtiyaçlarına bağlı ürün veya hizmetler hakkında bilgi sahibi olabilirler. Daha sonra alternatifleri değerlendirir ve keçe ihtiyacını karşılamak için kriterlerine en uygun olanı seçerler. Son olarak, bir işlem gerçekleştirilir ve satış sonrası hizmetler sağlanır. Çevrimiçi alışveriş tutumu, tüketicilerin internette alım yapmak açısından psikolojik durumunu ifade eder (Li ve Zhang, 2002).

Tüketicilerin online alışveriş davranışlarını incelemek, e-ticarette en önemli araştırma gündemlerinden biri olmuştur (Chen ve Tan, 2004). Online tüketici davranışlarının araştırılması; bilgi sistemleri,

12 | P a g e 
pazarlama, yönetim bilimi, psikoloji ve sosyal psikoloji gibi birçok disiplinde yapılmıştır; (Hoffman ve Novak, 1996; Koufaris, 2002; Grefen vd, 2003; Pavlou, 2003; Cheung vd, 2005; Zhou vd, 2007).

Bauer, ilk kez tüketici davranışlarında risk alma kavramını literatürde kavramsallaştırmıştır. Tüketicinin riskleri ve belirsizlikleri seçmesi, tüketici davranışı anlamında en önemli husustur. Bu risk ve belirsizlikleri seçme durumu tüketiciyi endişelendiğginde dahi üstesinden gelinir ve tüketici bireysel seçim kriterlerine göre riskle başa çıkma yöntemleri geliştirir. (Taylor, 1974). Peter ve Ryan (1976: 184-185) riskle ilgili dört temel varsayım üzerinde durmaktadırlar; 1. Ürünler ve markalar, sundukları hizmetler dışında tüketicinin bakış açısından bakıldıklarında hiçbir değer taşımaz. Ek olarak, sunulan hizmetler sadece finansal veya performans değişkenlerini değil aynı zamanda sosyal, psikolojik, kolaylık, güvenlik ve diğer tüketici ile ilgili boyutları da içermektedir. 2. Satın alma sırasında, tüketici üründen beklentilerini ve marka tarafindan sunulan hizmetleri dikkate alarak karar için mantıklı bir temel oluşturur. Satın alımın gerçekleşebilmesi için,

(1) alternatif markalardan ve markanın maliyetinden daha iyi bir hizmet paketi sunmak daha iyidir ve

(2) sunulan hizmet paketi ihtiyaç duyulan parayı tutmaktan daha iyi bir fayda sağlamalıdır. Onu almak için. Tabii ki, rasyonellik kavramının tüketicinin öznel beklentileriyle sınırlı olduğu unutulmamalıdır.

3. Ürün kategorisindeki markalar, tüketici tarafindan algılanan fark edilebilir farklara sahiptir ve bu farklar tüketicide belirgindir.

4. Bu ilk çerçevede, tüketicilerin beklenen zararları iskonto etmek ve riski önlemek için marka seçtikleri varsayılmaktadır.

Birçok çalışma, çevrimiçi alışveriş davranışını bağımsız olarak etkileyen çeşitli faktörleri incelemiş olsa da, bu çalışma; konuyla ilgili daha önceki çalışmalarda gözardı edilen ya da bileşik etkileri incelenmemiş olan "Algılanan Risk Faktörlerinin”, "Online Alş̧verişe Yönelik Tutum” üzerindeki etkisini açıklamak için yapılmıştır. Algılanan Risk Faktörlerinin etkilerini analiz ederek Online Alışveriş Davranışını farklı bir bakış açısı ile açıklamaya çalışılmışır. Genel olarak, bu çalışma çevrimiçi alışveriş davranışları hakkındaki bilgileri, davranışsal bakış açısından zenginleştirmektedir.

\subsection{Algılanan Risk Faktörlerinin Tutum Üzerine Etkisi}

Risk, mutlaka nesnel bir olmak zorunda değildir, algılanan risk de tüketici kararını etkileyen önemli bir faktördür. Algılanan risk, tüketicinin bir ürün veya hizmet almanın belirsizliği ve olumsuz sonuçları hakkındaki algıları olarak tanımlanabilir (Dowling ve Staelin, 1994). Bu nedenle, Algılanan risk, tüketicinin bir davranışın olası sonuçları ve olası bir kayıp hakkında endişe duymasına sebep olabilir (Forsythe ve Shi 2003).

Online alısverişte, tüketicilerin alışveriş davranışı üzerinde etkisi olabilecek risk faktörleri Kişisel Riskler (Finansal Risk gibi) olabileceği gibi; ürüne ya da sanal mağazaya bağlı riskler (ürünsel risk, uygunluk riski, teslimat ve iade politikaları, servis ve alt yapı değişkenleri) de olabilir. Bu risklerin her biri ayrı ayrı veya bileşik olarak tüketicinin satın alma davranışını ve bu davranışa yönelik tutumunu etkileyebilir.

\subsection{Finansal Risk}

Potansiyel para kaybı olarak tanımlanan Finansal Risk, tüketicilerin, online alışverişlerin önündeki en büyük engel olarak gösterilen çevrimiçi kredi kartı kullanımına ilişkin güvensizlik hissini içermektedir (Forsythe vd., 2006). Para kaybetme korkusu ve finansal detaylar; online alışveriş tutumunda önemli faktörlerdir. Para kaybetme riski ve kredi kartı bilgilerinin kopyalanması ihtimalinin artması online alışverişe karşı olan tutumu azaltmaktadır. Dolayısıyla finansal risk faktörü online alışveriş yapmamak için önemli bir faktördür (Javadi vd., 2012). Konuyla ilgili aşağıdaki hipotez oluşturulmuştur (Javadi vd, 2012):

H1: Para kaybetme riski ve finansal detaylar, online alışveriş davranışına yönelik tutum üzerinde negatif etkilidir.

\section{3. Ürünsel Risk}

Ürün performans riski, bir marka veya bir ürün beklendiği gibi performans göstermediğinde ortaya çıkan zarar olarak tanımlanmakta ve büyük ölçüde müşterilerin ürünün kalitesini çevrimiçi olarak doğru bir şekilde değerlendirememesinden kaynaklanmaktadır (Forsythe vd., 2006). Ürünsel Risk, sipariş edilen bir ürünün beklenen performansı karşılamaması sonucundaki kayıp maliyet olarak tanımlanabilir. Ürünsel risk, tüketicinin satın alacağı ürünün kalitesini ve performansını internet üzerinden değerlendirmesi konusundaki yetersizliğinin bir sonucu olabilir. İnternet üzerinden dokunma, deneme vb özellikler test edilememesi, hatalı ürün rengi, yetersiz ürün bilgisi gibi ürün kalite bileşenlerinin 
yetersizliği, online alışverişte ürünsel riskin önemini arttırmaktadır (Forsythe, 2006). Performans riski olarak da adlandırılan fonksiyonel risk, belirsizlik ve beklenen bir seviyede işlemeyen bir ürünün sonucu olarak da tanımlanmaktadır. Ürün performans riski, müşterinin ürün kalitesini doğru şekilde değerlendirememesi nedeniyle, kötü bir ürün seçiminden kaynaklanabilir. (Gerber vd,, 2014). Ürünsel riskle ilgili aşağıdaki hipotez oluşturulmuştur (Javadi vd., 2012):

H2: Ürünsel Risk, online alışverişe yönelik tutum üzerinde negatif etkilidir.

\subsection{Uygunluk Riski}

Uygunluk riski; sipariş teslimi, uygun web sitesinin bulunması ya da ürün teslimin ertelenmesi gibi zorluklara bağlı olarak ortaya çıkan zaman ve maliyet kaybı olarak tanımlanmaktadır. Bazı tüketiciler için bu durum önemli bir endişe konusudur. Uygunluk riskinin tüketicinin online alışveriş davranışına yönelik tutumunda önemli bir etken olduğu değerlendirilmektedir (Forsythe, 2006). Tüketicilerin algılanan uygunluk riski yüksek olduğunda, belirli online satın alma davranışlarını gerçekleştirmelerinin çok zor olduğunu düşünülmektedir. Uygunluk riskiyle ilgili aşağıdaki hipotez oluşturulmuştur (Javadi vd., 2012):

H3: Kullanıc dostu arayüze sahip ve müşteriye daha iyi bir yardım servisi sağlayan alışveriş siteleri, online alışverişe yönelik tutum üzerinde pozitif etkilidir.

\subsection{Teslimat Riski}

Teslim edilmeme riski, müşterilerin ürünleri çevrimiçi satın almaya karar vermesi durumunda en büyük endişelerden biridir. Malların kaybedilmesi, zarar görmesi ve çevrimiçi siparişin onaylanmasından sonra yanlış yere gönderilmesinden kaynaklanan olası teslimat başarısızlığı olarak tanımlanır. Tüketiciler teslimat sürecinde endişelidir; örneğin, nakliye sırasında hasar görebilir, yanlış adrese teslim edilebilir veya bazı durumlarda gecikebilir. Ürünlerin kullanımı ve tüketicilere taşınması sırasında zarar görebileceği korkusu da teslim edilememe riskinin bir parçasıdır (Ariff vd., 2014). Teslimat riski, ürünün kaybolması, hasar görmesi, yanlış adrese gönderilmesi gibi potansiyel aksaklıklarla ilgilidir. Tüketiciler, teslimatın çeşitli nedenlere bağlı olarak erteleneceği, kargo şirketinin anlaşılan zaman aralığında teslim etmeyeceği, kargo şirketinin taşıma ve transfer esnasında ürüne zarar vereceği ya da uygun olmayan ambalaj kullanacağı korkularını taşımaktadırlar (Masoud, 2013). Bazı çalışmalar, tüketicilerin, ürün teslimatı konusunda daha fazla endişe duyduklarını göstermektedir; örneğin, tüketiciler satın aldıkları ürünlerin, kararlaştırılan zaman aralığında teslim edilmemesi ve ürünlerin taşıma ve nakliye sırasında zarar görebilecekleri ya da farklı sebeplerden dolayı ürünün gecikeceği endişesini taşımaktadırlar (Claudia, 2012).

Teslim etmeme riskinin tüketici tutumuna önemli ve olumsuz yönde etki ettiğini göstermektedir.

Teslimat riskiyle ilgili aşağıdaki hipotez oluşturulmuştur (Javadi vd., 2012):

H4: Ürünün teslim edilmemesi korkusu, online alışverişe yönelik tutum üzerinde negatif etkiye sahiptir.

\section{6. İade Politikası}

Tüketiciler, internet üzerinden satın aldıkları ürünle ilgili, koşulsuz ve herhangi bir zorlanmaya maruz kalmadan iade edebilme, ücretsiz iade kargo imkanını aramaktadırlar. Satın alınan ürünün iadesiyle ilgili yaşanabilecek zorluklar, online alışverişi olumsuz yönde etkilemekte ve tüketicinin alışveriş yapıp yapmama kararında önemli rol oynamaktadır (Javadi vd., 2012). İade politikasıyla ilgili aşağıdaki hipotez oluşturulmuştur (Javadi vd., 2012):

H5: Siber kanunlar ve düşük iade kargo ücretleri online alışverişe yönelik tutum üzerinde pozitif etkilidir.

\subsection{Tutum}

Tutumlar, bireylerin bir nesne veya fikre yönelik sürekli ola duyguları, eğilimleri, taraftarlığı, tarafsızlığ1 ya da değerlendirmeleridir (Kılıç ve Göksel, 2004). Diğer bir deyişle tutum, kişinin objektif bir durum karşısında o durum ile ilgili düşünce, duygu ve davranışlarını düzenli bir biçimde belirleme tarzıdır.

Ajzen'e (1991) göre "Davranışsal Niyet”, bireyin motivasyon düzeyinin değerlendirilmesidir. Kişinin davranışı gerçekleştirmeye ya da çaba harcamaya ne kadar istekli olduğunun göstergesi de denebilir. Davranışsal niyet ne kadar güçlü olursa davranışı gerçekleştirme olasılığı da o kadar yüksek olur. Ancak bu durum, niyetin davranış üzerindeki etkisinin tamamıyla bireyin iradesine bağlı olduğu davranışlarda geçerlidir. Yani birey bir davranışı gerçekleştirmeyi veya gerçekleştirmemeyi seçebilir. Ancak bazı durumlarda birey iradesinden başka değişkenler de davranışı etkiyebilmektedir. Bu değişkenler kaynak 
yeterliliği, fırsat vb faktörler olabilir. Bunlar bireyin iradesi dışındaki etkenlerdir ve bu etkenler "Gerçek Davranışsal Kontrol” olarak adlandırılmaktadır (Yağcı ve Çabuk, 2014).

"Davranışa Yönelik Amaç”, bireyin davranışı gerçekleştirmek için harcadığı çaba olarak tanımlanabilir. "Davranışa Yönelik Tutum" ise, bireyin söz konusu davranışın gerçekleşmesine karşı negatif veya pozitif değerlendirmesidir.

Tutum, tüketicinin online alışveriş esnasında içinde bulunduğu psikolojik durumu tanımlar. Tüketici tutumunun alışveriş niyetini ve sonucunda bir işlem yapılıp yapılmayacağını etkilediğine inanılmaktadır. İnternet alışverişinde pozitif niyet pozitif tutumla ilgilidir ve tüketicinin online alışveriş yapma kararını etkiler (Li ve Zhang, 2002).

Halen, online alışveriş davranışları üzerinde en çok hangi tür risklerin etkilendiğini gösteren sınırlı deneysel kanıt bulunmaktadır. Çevrimiçi alışveriş ve çevrimiçi arama / satın alma davranışlarına yönelik genel tutumların, tüketicilerin hem işlevsel hem de işlevsel olmayan faydalara ilişkin algılarının yanı sıra çevrimiçi satın alma ile ilgili risk algılarından da etkilendiği değerlendirilmektedir (Forsythe vd., 2006).

\section{Kuramsal Model}

Çalışmada kullanılan model, Türk tüketicilerin, online satın alma davranışına yönelik tutumlarını etkileyen faktörleri analiz etmek için oluşturulmuştur. Araştırma için kullanılan kuramsal model şekil 3.1'deki gibidir.

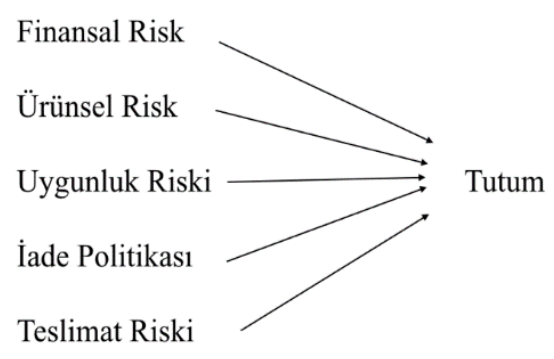

Şekil2.1. Araştırmanın Kuramsal Modeli

\section{Metodoloji}

Araştırmada, konu ile ilgili benzer araştırmalarda kullanılan ölçeklerden faydalanılmıştır. Kullanılan ölçekler dilimize çevrilip yapılan çalışmayla uyumlu hale getirilmiştir. Ölçek yapıları ve yararlanılan literatür Tablo 3.1'de gösterilmiştir.

Tablo 4.1: Araştırmanın Ölçek Yapıları ve Yararlanılan Literatür

\begin{tabular}{|l|l|l|}
\hline DEĞİ̧̧KEN & ARAŞTIRMACI & KULLANILMIŞ ÖLÇEKLER (ANKET SORULARI) \\
\hline Finansal Risk & $\begin{array}{l}\text { Javadi vd., 2012. } \\
\text { Swinyard ve Smith, 2003. } \\
\text { Forsythe, 2006. }\end{array}$ & $\begin{array}{l}\text { - Online alışveriş yaparsam kredi kartı bilgilerimin } \\
\text { gizliliğinin ihlal edilebileceğini ve hatalı } \\
\text { kullanılabileceğini hissediyorum. } \\
\text { - Online alışveriş yaptığım zaman, satıcı benim kredi kartı } \\
\text { bilgilerime sahip olacağ için fahiş fiyat ödeyebilirim. } \\
\text { - Satıcıya verdiğim bilgilerimin 3.kişilerle paylaş1larak } \\
\text { gizliliğimin ihlal edilebileceğini hissediyorum. }\end{array}$ \\
\hline Ürünsel Risk & $\begin{array}{l}\text { Javadi vd., 2012. } \\
\text { Swinyard ve Smith, 2003. } \\
\text { Forsythe, 2006. }\end{array}$ & $\begin{array}{l}\text { - Tam olarak sipariş ettiğim ürünü alamayabilirim. } \\
\text { - Elime geçen ürün arızalı olabilir } \\
\text { - Internet üzerinden ürünün kalitesini değerlendirmek } \\
\text { zordur. }\end{array}$ \\
\hline
\end{tabular}




\begin{tabular}{|c|c|c|}
\hline DEĞİŞKEN & ARAŞTIRMACI & KULLANILMIŞ ÖLÇEKLER (ANKET SORULARI) \\
\hline Uygunluk Riski & $\begin{array}{l}\text { Javadi vd., 2012. } \\
\text { ve Swinyard } \\
\text { Forsythe, } 2006 .\end{array}$ & $\begin{array}{l}\text { - Online olarak doğru ürünü bulmak zordur. } \\
\text { - Online alışveriş yaparsam ürün gelene kadar } \\
\text { sabredemem. } \\
\text { - Online alışveriş yaptığımda ürünü deneyemem. } \\
\text { - Online alış veriş yaptığımda anlaşmazlıkları çözmenin } \\
\text { daha zor olduğunu hissediyorum. } \\
\text { - Online alışverişte siparişi iptal etmek kolay değildir. } \\
\text { - Online alınan ürünü iade ederken problem yaşarım. } \\
\text { (ürünü geri kargolamak zorunda kalmak ve satıcının } \\
\text { güçlük çıkarmadan kabul etmesini beklemek. }\end{array}$ \\
\hline Teslimat Riski & $\begin{array}{l}\text { Forsythe, } 2006 . \\
\text { Javadi vd., } 2012 .\end{array}$ & $\begin{array}{l}\text { - Online sipariş verdiğim ürünü teslim alamayabilirim. } \\
\text { - Güvenilir ve iyi donanımlı kargo olmadığı için online } \\
\text { alışveriş yapmıyorum. }\end{array}$ \\
\hline İade Politikası & $\begin{array}{l}\text { Lewis, } 2006 . \\
\text { Javadi vd., } 2012 .\end{array}$ & $\begin{array}{l}\text { - Ücretsiz iade servisi yoksa online satın almam. } \\
\text { - Sadece ürünü koşulsuz iade edebilirsem online satın } \\
\text { alırım. } \\
\text { - Para iade garantisi yoksa online satın almam. }\end{array}$ \\
\hline Tutum & $\begin{array}{l}\text { George, } 2004 . \\
\text { Javadi vd., } 2012 .\end{array}$ & $\begin{array}{l}\text { - İnterneti, online alışveriş için kullanmak kolaydır. } \\
\text { - Online alışveriş eğlencelidir ve keyif alırım }\end{array}$ \\
\hline
\end{tabular}

Çalışmada kullanılan ölçekler; Finansal Risk, Ürünsel Risk ve Uygunluk Riski ölçekleri Javadi vd., (2012), Swinyard ve Smith, (2003) ve Forsythe, (2006)'nın daha önce kullandığı ölçeklerden; Teslimat Riski ölçeği Forstythe (2006) ve Javadi, (2012)'nin kullanmış olduğu ölçekten; İade Politikası ölçeği ve Tutum ölçeği George (2004) ve Javadi vd. (2012) ölçeklerinden; dilimize çevrilerek çalışmaya uyarlanmıştır.

\section{Veri Analizi ve Sonuçları}

Seçilen ölçekler, yapılan çalışmayla uyumlu çalışmalardan seçilmiştir. Veriler anket yöntemiyle toplanmıştır. Sadece online alışveriş deneyimi olan tüketicilere uygulanan anket soruları 5'li Likert Ölçeği kullanılarak ölçülmüştür: 1 = Kesinlikle katılmıyorum, 2 = Katılmıyorum, 3 = Ne Katılıyorum ne Katılmıyorum, 4 = Katılıyorum ve $5=$ Kesinlikle katılıyorum. Sanal ortamda Google Drive aracılığıyla oluşturulan anket, internet kullanıcılarına yönelik olduğu için, hedef kitleye ulaştırılmasında sosyal medya ve mail kullanılmıştır. Anket katılımcılarının cevapları elektronik veri havuzunda toplanmıştır. Anketi yanıtlayan 440 kişiden 2'si hiçbir ölçek sorusunu yanıtlamadığı için bu 2 kişi analizlere dahil edilmemiş ve tüm analizler 438 kişi üzerinden yürütülmüştür. Anket çalışması ile toplanan veriler SPSS (Statistical Package for the Social Sciences) programı kullanılarak analizi yapılan verilerin öncelikle güvenilirlik ve geçerlilik analizleri yapılmış, daha sonra ifadeler için tamamlayıcı istatistiki analizler yapılmıştır.

\subsection{Demografik Özellikler}

$\mathrm{Bu}$ çalışmada, kişilerin online alışveriş davranışlarını etkileyen faktörleri belirlemek için 26 adet ölçek kullanılmıştır. Tüm analizler, anketi yanıtlayan 438 kişi üzerinden yürütülmüşsür. Anketi yanıtlayanlara ait demografik özellikler Tablo 4.1.'de verilmiştir.

Araştırma sorusu 1: Online tüketicilerin demografik özellikleri nelerdir? 
Tablo 5.1. Demografik özellikler

\begin{tabular}{|c|c|c|c|}
\hline & & $\mathbf{n}$ & $\%$ \\
\hline \multirow{2}{*}{ Cinsiyet } & Erkek & 143 & 32,9 \\
\hline & Kadın & 291 & 67,1 \\
\hline \multirow{5}{*}{ Yaş } & 21 ve alt 1 & 74 & 17,0 \\
\hline & $22-29$ & 147 & 33,8 \\
\hline & $30-39$ & 149 & 34,3 \\
\hline & $40-49$ & 35 & 8,0 \\
\hline & 50 ve üstü & 30 & 6,9 \\
\hline \multirow{4}{*}{ Eğitim } & Lise & 131 & 30,3 \\
\hline & Üniversite & 238 & 55,0 \\
\hline & Yüksek Lisans & 43 & 9,9 \\
\hline & Doktora & 21 & 4,8 \\
\hline \multirow{5}{*}{ Aylık Gelir } & 1000 TL ve alt 1 & 115 & 26,8 \\
\hline & $1001-3000 \mathrm{TL}$ & 126 & 29,4 \\
\hline & $3001-4000 \mathrm{TL}$ & 71 & 16,6 \\
\hline & $4001-5000 \mathrm{TL}$ & 31 & 7,2 \\
\hline & 5001 TL ve üzeri & 86 & 20,0 \\
\hline \multirow{11}{*}{ Meslek } & Bilgi ve iletişim & 20 & 4,6 \\
\hline & Bilim ve mühendislik & 55 & 12,6 \\
\hline & Eğitim & 45 & 10,3 \\
\hline & Emekli & 14 & 3,2 \\
\hline & Hukuk, sosyal ve kültürel & 28 & 6,4 \\
\hline & İş ve yönetim & 49 & 11,2 \\
\hline & Öğrenci & 104 & 23,7 \\
\hline & Sağlık & 37 & 8,4 \\
\hline & Silahlı kuvvetler & 6 & 1,4 \\
\hline & Turizm, seyahat ve konaklama & 30 & 6,8 \\
\hline & Diğger & 50 & 11,4 \\
\hline
\end{tabular}

Anketi yanıtlayanların \%32,9'u erkek, \%67,1'i ise kadındır. Yaş dağılımlarına bakıldığında ise \%85,1 kişinin 40 yaş altı olduğu görülmektedir. Anketi yanıtlayan kişilerin \%55'i üniversite, \%30,3’ü lise, $\% 9,9$ 'u yüksek lisans ve \%4,8'i ise doktora mezunudur. Aylık gelire göre bir sıralama yapıldığında çoğunluğun $(\% 56,2) 3000$ TL ve altı bir aylık gelire sahip olduğu görülmektedir. Meslek gruplarında en yüksek yüzdeye sahip grup öğrenci $(\% 23,7)$ iken en düşük silahlı kuvvetlere mensup çalışanlarıdır $(\% 1,4)$. 


\section{2. Ölçek Skorlarının Dağılımı ve Güvenilirlik Skorları}

Anketi yanıtlayanların her bir ölçek sorusuna verdiği skorların ve ölçek toplam skorlarının ortalamaları ve standart sapmaları Tablo 4.2.'de verilmektedir.

Tablo 5.2. Risk Faktörlerinin Ölçek Sorularının ve Toplam Skorların Dağılımı

\begin{tabular}{|c|c|c|c|c|c|}
\hline \multicolumn{2}{|c|}{ Ölçek soruları ve ölçek toplam skorları } & \multirow{2}{*}{$\begin{array}{l}\text { Min } \\
1\end{array}$} & \multirow{2}{*}{$\begin{array}{l}\text { Max } \\
5\end{array}$} & \multirow{2}{*}{$\begin{array}{l}\text { Ortalama } \\
3,23\end{array}$} & \multirow{2}{*}{$\begin{array}{c}\text { SS } \\
1,11\end{array}$} \\
\hline \multirow{4}{*}{ Finansal Risk } & 1 & & & & \\
\hline & 2 & 1 & 5 & 2,67 & 1,05 \\
\hline & 3 & 1 & 5 & 3,21 & 1,06 \\
\hline & Toplam & 3 & 15 & 9,11 & 2,73 \\
\hline \multirow{4}{*}{ Ürünsel Risk } & 1 & 1 & 5 & 3,52 & 1,01 \\
\hline & 2 & 1 & 5 & 3,60 & ,91 \\
\hline & 3 & 1 & 5 & 3,86 & ,95 \\
\hline & Toplam & 3 & 15 & 10,98 & 2,46 \\
\hline \multirow{7}{*}{$\begin{array}{l}\text { Uygunluk } \\
\text { Risk }\end{array}$} & 1 & 1 & 5 & 2,54 & 1,07 \\
\hline & 2 & 1 & 5 & 2,86 & 1,15 \\
\hline & 3 & 1 & 5 & 3,99 & ,98 \\
\hline & 4 & 1 & 5 & 3,42 & 1,16 \\
\hline & 5 & 1 & 5 & 2,91 & 1,09 \\
\hline & 6 & 1 & 5 & 3,44 & 1,14 \\
\hline & Toplam & 6 & 30 & 19,16 & 4,55 \\
\hline \multirow{3}{*}{ Teslimat Risk } & 1 & 1 & 5 & 2,78 & 1,02 \\
\hline & 2 & 1 & 5 & 2,26 & ,97 \\
\hline & Toplam & 2 & 10 & 5,04 & 1,67 \\
\hline \multirow{4}{*}{ İade Politikası } & 1 & 1 & 5 & 3,67 & 1,08 \\
\hline & 2 & 1 & 5 & 3,57 & 1,11 \\
\hline & 3 & 1 & 5 & 3,80 & 1,06 \\
\hline & Toplam & 3 & 15 & 11,04 & 2,84 \\
\hline \multirow{4}{*}{ Servis Altyapı } & 1 & 1 & 5 & 3,88 & 1,07 \\
\hline & 2 & 1 & 5 & 4,40 &, 82 \\
\hline & 3 & 1 & 5 & 3,07 & 1,07 \\
\hline & Toplam & 3 & 15 & 11,34 & 2,00 \\
\hline
\end{tabular}

Ölçeklerdeki her bir soru 5'li likert skor (Kesinlikle Katılmıyorum-...-Kesinlikle Katıllyorum) olacak şekilde hazırlanmış ve ankete katılanlar tarafından bu şekilde yanıtlanmıştır. Çalışmada ölçeklerin ayrı 
ayrı güvenirliğinin ve toplam anket güvenirliğinin ölçülmesinde ve belirtilmesinde Cronbach alfa katsayıları kullanılmıştır. Literatürde genellikle, Cronbach alfa $\geq 0,70$ olması güvenilirliğin kabul edilebilir düzeyde olduğunu göstermektedir (Kline, 2005; Polit ve Beck, 2004). Bu çalışmada, Cronbach alfa değerleri 0,578 ile 0,819 aralığında değişmektedir. Sadece teslimat riski, servis altyap1, ve tutum ölçeklerinin alfa değerleri eşik değerin altında kalmış olup güvenilirliği kanıtlanamamıştır. Tüm anket sorularına verilen cevapların güvenilirliği incelendiğinde 0,811 alfa değeri elde edilmiştir ve bu da anketin güvenilir olduğunu göstermektedir.

Tablo 5.3. Ölçek Güvenilirlik Skorları

\begin{tabular}{ll}
\hline Ölçekler & Cronbach Alfa \\
\hline Finansal Risk & 0,804 \\
\hline Ürünsel Risk & 0,819 \\
\hline Uygunluk Risk & 0,778 \\
\hline Teslimat Risk & 0,578 \\
\hline İade Politikası & 0,847 \\
\hline Tutum & 0,654 \\
\hline
\end{tabular}

\subsection{Online alışveriş seçenekleri kullanım örüntüleri}

Yapılan çalışmada, tüketicilerin online alışveriş davranışlarına ait alışkanlıkları ve kullanım sıklıkları da ölçülmüştür.

Araştırma Sorusu 2: Online tüketicilerin en sık satın aldıkları ürünler ve sıklıkları nelerdir?

Tablo 5.4. Online alışveriş seçenekleri kullanım sıklıklarına göre dağılımları (n(\%))

\begin{tabular}{|c|c|c|c|c|c|c|c|c|}
\hline Sira & CD-DVD & Kitap & $\begin{array}{l}\text { Sağlık ve } \\
\text { kozmetik }\end{array}$ & $\begin{array}{c}\text { Giyim, } \\
\text { ayakkabı } \\
\text { ve } \\
\text { aksesuar }\end{array}$ & Elektronik & $\begin{array}{c}\text { Bankacılık } \\
\text { İşlemleri }\end{array}$ & $\begin{array}{c}\text { Ulaşım ve } \\
\text { Rezervasyon }\end{array}$ & $\begin{array}{c}\text { Otel ve tur } \\
\text { rezervasyonu }\end{array}$ \\
\hline 1 & $6(2)$ & $48(14,1)$ & $25(7,9)$ & $85(24,9)$ & $16(5,4)$ & $138(41,6)$ & $72(20,2)$ & $7(2,3)$ \\
\hline 2 & $8(2,7)$ & $47(13,8)$ & $40(12,6)$ & $78(22,8)$ & $26(8,7)$ & $57(17,2)$ & $92(25,8)$ & $22(7,1)$ \\
\hline 3 & $9(3)$ & $47(13,8)$ & $38(11,9)$ & $60(17,5)$ & $44(14,7)$ & $50(15,1)$ & $58(16,3)$ & $52(16,7)$ \\
\hline 4 & $14(4,7)$ & $42(12,4)$ & $41(12,9)$ & $54(15,8)$ & $57(19,1)$ & $31(9,3)$ & $54(15,2)$ & $48(15,4)$ \\
\hline 5 & $26(8,7)$ & $55(16,2)$ & $62(19,5)$ & $29(8,5)$ & $59(19,7)$ & $18(5,4)$ & $26(7,3)$ & $36(11,6)$ \\
\hline 6 & $62(20,7)$ & $52(15,3)$ & $46(14,5)$ & $18(5,3)$ & $51(17,1)$ & $14(4,2)$ & $27(7,6)$ & $26(8,4)$ \\
\hline 7 & $86(28,8)$ & $42(12,4)$ & $42(13,2)$ & $10(2,9)$ & $24(8)$ & $15(4,5)$ & $18(5,1)$ & $49(15,8)$ \\
\hline 8 & $88(29,4)$ & $7(2,1)$ & $24(7,5)$ & $8(2,3)$ & $22(7,4)$ & $9(2,7)$ & $9(2,5)$ & $71(22,8)$ \\
\hline
\end{tabular}

Araştırma Sorusu 3: Alışveriş seçenekleri cinsiyete göre farklılık göstermekte midir?

19 | P a g e

www.iiste.org 
Tablo 5.5. Cinsiyete göre alışveriş seçenekleri kullanım sıklıkları

\begin{tabular}{|c|c|c|c|c|c|c|c|c|c|c|}
\hline \multicolumn{11}{|c|}{ Independent Samples Test } \\
\hline & & \multicolumn{2}{|c|}{$\begin{array}{l}\text { Levene's Test for Equality of } \\
\text { Variances }\end{array}$} & \multicolumn{7}{|c|}{ t-test for Equality of Means } \\
\hline & & \multirow[t]{2}{*}{ 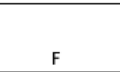 } & \multirow[b]{2}{*}{ Sig. } & \multirow[b]{2}{*}{$\mathrm{t}$} & \multirow[b]{2}{*}{ df } & \multirow{2}{*}{$\begin{array}{l}\text { Sig. }(2- \\
\text { tailed) }\end{array}$} & \multirow{2}{*}{$\begin{array}{c}\text { Mean } \\
\text { Difference }\end{array}$} & \multirow{2}{*}{$\begin{array}{l}\text { Std. Error } \\
\text { Difference }\end{array}$} & \multicolumn{2}{|c|}{$\begin{array}{l}\text { 95\% Confidence Interval of } \\
\text { the Difference }\end{array}$} \\
\hline & & & & & & & & & Lower & Upper \\
\hline \multirow[t]{2}{*}{ cddvd } & $\begin{array}{l}\text { Equal variances } \\
\text { assumed }\end{array}$ & \multirow[t]{2}{*}{, 474} & \multirow[t]{2}{*}{, 491} & \multirow{2}{*}{$\begin{array}{l}251 \\
\text { 263 }\end{array}$} & \multirow{2}{*}{$\begin{array}{r}297 \\
214,472\end{array}$} & \multirow{2}{*}{$\begin{array}{r}, 802 \\
, 793\end{array}$} & \multirow{2}{*}{$\begin{array}{r}, 052 \\
, 052\end{array}$} & \multirow{2}{*}{$\begin{array}{r}, 207 \\
, 197\end{array}$} & \multirow{2}{*}{$\begin{array}{l}-, 355 \\
-, 337\end{array}$} & \multirow{2}{*}{$\begin{array}{l}\text {,459 } \\
440\end{array}$} \\
\hline & $\begin{array}{l}\text { Equal variances } \\
\text { not assumed }\end{array}$ & & & & & & & & & \\
\hline \multirow[t]{2}{*}{ kitap } & $\begin{array}{l}\text { Equal variances } \\
\text { assumed }\end{array}$ & \multirow[t]{2}{*}{, 041} & \multirow[t]{2}{*}{840} & 2,379 & 338 & ,018 &, 566 & ,238 & ,098 & 1,033 \\
\hline & $\begin{array}{l}\text { Equal variances } \\
\text { not assumed }\end{array}$ & & & 2,356 & 198,329 & ,019 &, 566 & ,240 & ,092 & 1,039 \\
\hline \multirow[t]{2}{*}{ saglikkozmetik } & $\begin{array}{l}\text { Equal variances } \\
\text { assumed }\end{array}$ & \multirow[t]{2}{*}{6,264} & \multirow[t]{2}{*}{013} & 5,923 & 316 &, 000 & 1,394 &, 235 & ,931 & 1,857 \\
\hline & $\begin{array}{l}\text { Equal variances } \\
\text { not assumed }\end{array}$ & & & 6,305 & 221,141 &, 000 & 1,394 &, 221 & ,958 & 1,829 \\
\hline \multirow[t]{2}{*}{$\begin{array}{l}\text { giyimayakkabiak } \\
\text { sesuar }\end{array}$} & $\begin{array}{l}\text { Equal variances } \\
\text { assumed }\end{array}$ & \multirow[t]{2}{*}{5,175} & \multirow[t]{2}{*}{,024 } & 3,261 & 340 & ,001 & ,678 & ,208 & ,269 & 1,088 \\
\hline & $\begin{array}{l}\text { Equal variances } \\
\text { not assumed }\end{array}$ & & & 3,064 & 175,632 &, 003 & ,678 &, 221 & ,241 & 1,115 \\
\hline \multirow[t]{2}{*}{ elektronikesya } & $\begin{array}{l}\text { Equal variances } \\
\text { assumed }\end{array}$ & \multirow[t]{2}{*}{001} & \multirow[t]{2}{*}{972} & $-6,597$ & 297 &, 000 & $-1,382$ & ,210 & $-1,794$ &,- 970 \\
\hline & $\begin{array}{l}\text { Equal variances } \\
\text { not assumed }\end{array}$ & & & $-6,640$ & 217,384 &, 000 & $-1,382$ & ,208 & $-1,792$ &,- 972 \\
\hline \multirow[t]{2}{*}{ bankacilik } & $\begin{array}{l}\text { Equal variances } \\
\text { assumed }\end{array}$ & 8,016 & ,005 & $-2,723$ & 329 &, 007 &,- 614 &, 226 & $-1,058$ &,- 170 \\
\hline & $\begin{array}{l}\text { Equal variances } \\
\text { not assumed }\end{array}$ & & & $-2,908$ & 259,377 &, 004 &,- 614 &, 211 & $-1,030$ &,- 198 \\
\hline otobusucakbileti & $\begin{array}{l}\text { Equal variances } \\
\text { assumed }\end{array}$ & 4,870 & ,028 & $-1,144$ & 353 &, 253 &,- 246 & ,215 &,- 669 & 177 \\
\hline & $\begin{array}{l}\text { Equal variances } \\
\text { not assumed }\end{array}$ & & & $-1,188$ & 251,544 &, 236 &,- 246 & ,207 &,- 654 & , 162 \\
\hline $\begin{array}{l}\text { otelturrezervasyo } \\
\mathrm{n}\end{array}$ & $\begin{array}{l}\text { Equal variances } \\
\text { assumed }\end{array}$ &, 347 &, 556 &,- 695 & 308 &, 488 &,- 178 &, 256 &,- 681 &, 326 \\
\hline & $\begin{array}{l}\text { Equal variances } \\
\text { not assumed }\end{array}$ & & &,- 696 & 204,356 & ,487 &,- 178 & ,256 &,- 682 &, 326 \\
\hline
\end{tabular}

T testi sonucuna göre otobüs-uçak bileti ve otel-tur rezervasyonu kullanımı dışındaki online alışveriş tercihleri cinsiyete göre farklılık göstermektedir. Erkek kullanıcıların elektronik eşya alma sıklıklarının daha çok olması beklense de kadınların elektronik eşya alma sıklıklarının daha fazla olduğu görülmüştür.

Tablo 5.6. Cinsiyete Göre Alışveriş Tercihleri

\begin{tabular}{|c|c|c|c|c|c|c|c|c|}
\hline & \multicolumn{8}{|c|}{ Cinsiyet } \\
\hline & \multicolumn{4}{|c|}{ Erkek } & \multicolumn{4}{|c|}{ Kadın } \\
\hline & Min & Max & Ortalama & SS & Min & Max & Ortalama & SS \\
\hline Cd_Dvd & 2 & 8 & 6,43 & 1,52 & 1 & 8 & 6,38 & 1,74 \\
\hline Kitap & 1 & 8 & 4,47 & 2,07 & 1 & 8 & 3,91 & 2,01 \\
\hline Sağlık_kozmetik & 1 & 8 & 5,54 & 1,72 & 1 & 8 & 4,14 & 2,03 \\
\hline Giyim_ayakkabı_aksesuar & 1 & 8 & 3,46 & 1,98 & 1 & 8 & 2,78 & 1,68 \\
\hline Elektronik & 1 & 8 & 3,70 & 1,70 & 1 & 8 & 5,08 & 1,74 \\
\hline Bankacılıkİşlemleri & 1 & 8 & 2,24 & 1,68 & 1 & 8 & 2,85 & 2,05 \\
\hline UlaşımveRezervasyon & 1 & 8 & 3,03 & 1,76 & 1 & 8 & 3,27 & 1,97 \\
\hline Otel_TurRezervasyon & 1 & 8 & 5,18 & 2,12 & 1 & 8 & 5,36 & 2,12 \\
\hline
\end{tabular}

\section{4. Çalışma Hipotezlerinin Test Edilmesi-Regresyon Analizi}

$\mathrm{Bu}$ çalışmada, her bir bağımsız değişkenin bağımlı değişkenle olan ilişkisini incelemek ve bağımlı değişkeni hangi yönde ve ne kadar açıkladığını belirmek amacıyla basit doğrusal regresyon analizi 
yapılmış ve çalışmanın hipotezleri araştırılmıştır. Bu analiz yöntemini kullanabilmek için öncelikle aşağıda belirtilen iki varsayımın sağlanması gerekmektedir;

- Hata terimlerinin birbirinden bağımsız olması bağımsızlı̆̆

- Bağımlı ve bağımsız değişken arasında doğrusal ilişki olması

- Hata terimlerinin normal dağılması

Hata terimlerinin birbirinden bağımsız olmasının test edilmesinde Durbin-Watson testi kullanılmıştır. Bağımlı ve bağımsız değişken arasındaki ilişkinin doğrusal olup olmadığının kontrol edilmesi amacıyla her bir hipotez için saçılım grafiği çizdirilmiş ve varsayım kontrol edilmiştir. Çalışmanın tüm hipotezleri için yukarıdaki varsayımlar test edilmiş ve sağlanmıştır.

Bu bölümde algılanan risk faktörleri ile tutum arasındaki ilişki incelenmiş ve regresyon analizi sonuçları verilmiştir. Çalışmanın hipotezleri;

- H1: Para kaybetme riski ve finansal detaylar, online alışveriş davranışına yönelik tutum üzerinde negatif etkilidir.

- $\quad$ H2: Ürünsel Risk, online alışverişe yönelik tutum üzerinde negatif etkilidir.

- H3: Uygunluk Risk, online alışverişe yönelik tutum üzerinde negatif etkilidir.

- H4: Teslimat risk, online alışverişe yönelik tutum üzerinde negatif etkilidir.

Değişkenler korelasyon analizine tabi tutulduğunda; İade Politikası değişkeni anlamlı olmadığı için Regresyon analizine dahil edilmemiştir.

\section{Tablo 5.7. Regresyon Analizi Model Özeti}

\begin{tabular}{|c|c|c|c|c|c|c|c|c|c|c|}
\hline \multirow[b]{3}{*}{ Model } & \multicolumn{9}{|c|}{ Model Summary ${ }^{\circ}$} & \multirow[b]{3}{*}{$\begin{array}{l}\text { Durbin- } \\
\text { Watson }\end{array}$} \\
\hline & & & & & \multicolumn{5}{|c|}{ Change Statistics } & \\
\hline & $\mathrm{R}$ & $R$ Square & $\begin{array}{l}\text { Adjusted R } \\
\text { Square }\end{array}$ & $\begin{array}{l}\text { Std. Error of } \\
\text { the Estimate }\end{array}$ & $\begin{array}{l}\text { R Square } \\
\text { Change }\end{array}$ & F Change & df1 & $\mathrm{df2}$ & Sig. F Change & \\
\hline 1 & $340^{2}$ &, 115 &, 107 & .63628 &, 115 & 14,121 & 4 & 433 &, 000 & 1,864 \\
\hline
\end{tabular}

a. Predictors: (Constant), TeslimatRiskOrt, FianasalRiskOrt, UygunlukRiskOrt, UrunselRiskOrt

b. Dependent Variable: TutumOrt

Regresyon modeli tablosundaki R Square, bağımsız değişkenlerdeki değişimin, bağımlı değişkendeki değişimin ne kadarını açıkladığını göstermektedir (Altunışık, Coşkun, Bayraktaroğlu, 2012). Bağımsız değişkenler, Bağımlı Değişkenlerdeki değişimin \%11,5'ini açıklamaktadır.

Model Tablosunda Durbin-Watson katsayısı 1.864 olarak bulunmuş ve modelin anlamlı olduğu görülmüştür.

B katsayısı, (-) işaretli olduğu için; bağımlı değişkenle bağımsız değişken arasındaki ilişkinin yönünün negatif olduğunu göstermektedir. B katsayısı incelendiğinde; Finansal Risk değişkeni ( $-0,165)$, Alışverişe Yönelik Tutum üzerinde negatif yönlü ancak düşük bir ilişkisi olduğu görülmektedir. Uygunluk Risk değişkeni (-0,071) negatif yönlü ancak düşük bir ilişkiyi göstermekte; Teslimat Riski de $(-0,099)$ yine negatif yönlü ancak zayıf bir ilişki olduğunu göstermektedir. Ürünsel Risk Değişkeninin B katsayısı 0,005 olarak çok düşük pozitif yönlü bir ilişki olduğu tespit edilmiştir.

Tablo 5.8. Coefficients

\begin{tabular}{|c|c|c|c|c|c|c|c|c|c|c|c|}
\hline \multicolumn{12}{|c|}{ Coefficients $^{a}$} \\
\hline \multirow[b]{2}{*}{ Model } & & \multicolumn{2}{|c|}{ Unstandardized Coefficients } & \multirow{2}{*}{$\begin{array}{c}\begin{array}{c}\text { Standardized } \\
\text { Coefficients }\end{array} \\
\text { Beta }\end{array}$} & \multirow[b]{2}{*}{ t } & \multirow[b]{2}{*}{ Sig. } & \multicolumn{2}{|c|}{$95.0 \%$ Confidence Interval for } & \multicolumn{3}{|c|}{ Correlations } \\
\hline & & $B$ & Std. Error & & & & Lower Bound & Upper Bound & Zero-order & Partial & Part \\
\hline \multirow[t]{5}{*}{1} & (Constant) & 5,097 & ,154 & & 32,991 & 000 & 4,793 & 5,400 & & & \\
\hline & FianasalRiskOrt &,- 165 & ,041 &,- 223 & $-4,055$ & 000 &,- 245 &,- 085 &,- 302 &,- 191 &,- 183 \\
\hline & UrunselRiskOrt & ,005 & ,049 & ,006 & ,094 & 925 &,- 093 & 102 &,- 214 & ,004 & ,004 \\
\hline & UygunlukRiskOrt &,- 071 & ,053 &,- 080 & $-1,346$ & 179 &,- 174 & ,033 &,- 238 &,- 065 &,- 061 \\
\hline & TeslimatRiskOrt &,- 099 & 044 &,- 123 & $-2,249$ & ,025 &,- 186 &,- 012 &,- 246 &,- 107 &,- 102 \\
\hline
\end{tabular}


Finansal Risk ve Teslimat Riski değişkenlerinin Sig. değeri 0,05'ten düşük olduğu için modele anlamlı katkı sağlarken; diğer değişkenlerin anlamlı br katkısı olmadığı tespit edilmiştir.

Regresyon modelinin açıklayıcılığının istatistiksel açıdan anlamlı olduğu görülmektedir $(F=14,121$, Sig=0,000).

\section{Tablo 5.9. Anova Analizi}

\begin{tabular}{|c|c|c|c|c|c|c|}
\hline \multicolumn{7}{|c|}{ ANOVA $^{a}$} \\
\hline & & $\begin{array}{l}\text { Sum of } \\
\text { Squares }\end{array}$ & df & Mean Square & $\mathrm{F}$ & Sig. \\
\hline \multirow[t]{3}{*}{1} & Regression & 22,867 & 4 & 5,717 & 14,121 &, $000^{6}$ \\
\hline & Residual & 175,300 & 433 &, 405 & & \\
\hline & Total & 198,167 & 437 & & & \\
\hline
\end{tabular}

\section{Tartışma}

H1, H2, H4 hipotezleri desteklenmiş, H3 hipotezi ise reddedilmiştir. Para kaybetme riski ve kredi kartı bilgilerinin ifşa edilme, ele geçirilme olasılığı (H1) arttıkça, online alışverişe yönelik tutum azalmaktadır. Bu bulgu Forsythe ve Shi (2003) ve Biswas ve Biswas (2004) bulgularıyla uyumludur. Bu çalışmalarda, finansal risk online alışveriş için önemli bir faktördür. Ayrıca, siparişin teslim edilmemesi olasılı̆̆ı (H4), online alışverişe yönelik tutumu düşürmektedir. Teslim edilmeme riski, online alışverişe yönelik tutum ve dolayısıyla alışveriş davranışı etkileyen önemli bir faktör olduğunu göstermektedir. Sipariş ettikleri ürünlerin teslim edilip edilmeyeceği konusunda tereddüt yaşayan insanlar, internetten alışveriş yapma eğiliminde olmazlar. Online satıcıların, tüketicide güven inşa etmesi konusunda ciddiyet ve çaba içinde olmamaları da alışveriş davranışı konusunda önemli bir etken haline gelmektedir. Teslimat riskinin online alışverişe yönelik tutum üzerindeki negatif etkisi , Javadi vd (2012) çalışmasında reddedilmekle birlikte bu çalışmada, etkili olduğu bulunmuştur. Hipotez H2 ve H3 testinin sonuçları, ürün risklerinin ve uygunluk riskinin çevrimiçi alışverişe yönelik tutum üzerindeki sınırlı bir etkisi olduğunu göstermiştir. Bulgular, Forsythe ve Shi (2003), Biswas ve Biswas (2004) bulguları ile tutarlıdır. Ürün ve uygunluk riski, online ortamda alı̧veriş yapmamanın önemli risk faktörleridir.

Tablo 6.1. Hipotezler ve Kabul/Red Durumları

\begin{tabular}{|l|l|}
\hline HIPOTEZLER & KABUL / RED \\
\hline $\begin{array}{l}\text { H1: Para kaybetme riski ve finansal detaylar, online } \\
\text { alışveriş davranışına yönelik tutum üzerinde negatif } \\
\text { etkilidir. }\end{array}$ & $\begin{array}{l}\text { Desteklenmektedir. } \\
\mathrm{p}<0,001 ; \mathrm{R}=0,302 \mathrm{R}^{2}=0,091 ; \mathrm{F}_{(14.121)}=\mathrm{p}<0,001\end{array}$ \\
\hline $\begin{array}{l}\text { H2: Ürünel Risk, online alışverişe yönelik tutum } \\
\text { üzerinde negatif etkilidir. }\end{array}$ & $\begin{array}{l}\text { Desteklenmektedir. } \\
\mathrm{p}<0,001 ; \mathrm{R}=0,214 \mathrm{R}^{2}=0,046 ; \mathrm{F}_{(14.121)}=\mathrm{p}<0,001\end{array}$ \\
\hline $\begin{array}{l}\text { H3: Uygunluk Risk, online alışverişe yönelik tutum } \\
\text { üzerinde negatif etkilidir. }\end{array}$ & $\begin{array}{l}\text { Reddedilmektedir. } \\
\mathrm{p}<0,001 ; \mathrm{R}=0,238 \mathrm{R}^{2}=0,057 ; \mathrm{F}_{(14.121)}=\mathrm{p}<0,001\end{array}$ \\
\hline $\begin{array}{l}\text { H4 : Teslimat risk, online alışverişe yönelik tutum } \\
\text { üzerinde negatif etkilidir. }\end{array}$ & $\begin{array}{l}\text { Desteklenmektedir. } \\
\mathrm{p}<0,05 ; \mathrm{R}=0,129 \mathrm{R} 2=0,017 ; \mathrm{F}_{(14.121)}=\mathrm{p}=0,007\end{array}$ \\
\hline
\end{tabular}




\section{Sonuç}

İnternetin insan hayatında hızla yaygınlaşmasıyla değişen insan hayatlarına paralel olarak, tüketicilerin davranışları da değişmektedir. Online alışveriş tüketicilere zaman kazandırmak, coğrafi kısıtllılıkları ortadan kaldırmak, ürün yelpazesini genişletmek gibi pek çok avantaj sağlamakta ve bu sayede de giderek büyüyen bir ekonomiye sahip olmaktadır. Bununla birlikte; internet üzerinden yapılan her türlü işlem, geleneksel yöntemlere göre daha net ve kolay ölçümlenebildiği için; firmalara da tüketici davranışlarını daha kolay izleme imkanı sağlamaktadır. Firmalar, izleyebildikleri ve ölçümleyebildikleri bu davranışların analiz edilerek alışveriş davranışına dönüşmesi için yapılabilecekleri belirlemeye çalışmakta; araştırmacılar da aynı şekilde, bunları analiz ederek online tüketicilerin davranışlarını anlamaya çalışmaktadır. Giderek büyüyen online ticaret pastası, araştırmacıların ve firmaların dikkatini, sayıları ve harcama miktarları giderek artan online tüketiciler üzerine çekmektedir.

Tüketicilerin alışveriş davranışını gerçekleştirmesi ya da gerçekleştirmemesinin nelere bağlı olduğu, karar aşamasında nelerden etkilendiğinin tespiti, pazarlama dünyası için en önemli sorulardan biridir. İnternet alışverişlerinin giderek artması; online alışverişin geleneksel alışverişten daha sık kullanılacağ 1 fikrini doğurmakta ve bu nedenle de online tüketicilerin davranışlarının da analiz edilmesinin önemi artmaktadır.

İnternet pazarlamasının geleceğini anlamak ve yön verebilmek için, tüketicilerin online alışveriş deneyimlerini anlamak gerekmektedir. Online alışveriş deneyimi çerçevesi hem firmalar hem de araştırmacılar için yararlı olabilir; online pazarlamacılar ve web sitesi tasarımcılarına, online firmaları tasarlarken ve inşa ederken veya mevcut online girişimlerini değerlendirirken özel dikkat gerektiren sorunları belirlemelerine yardımcı olabilir. Akademik araştırmacılar için ise, online tüketicinin davranışının daha iyi haritalanmasına yol açan yeni hipotezlerin ve araştırma sorularının formülasyonu için bir temel oluşturabilir. Çerçeve aynı zamanda, online alışveriş davranışını etkileyen unsurların doğasını ve ağırlığını daha da iyi anlamaya odaklanan daha ileri araştırmaların temelini oluşturabilir.

Günümüz ekonomik, ticari ve sosyal hayatının önemli bir parçası olan ve önemi giderek artmaya devam eden online alışverişte tüketici davranışları, araştırılmaya ve üzerinde çalışılmaya devam edilecek konulardan biri olarak güncelliğini koruyacaktır.

\section{Kaynaklar}

Ajzen, Icek, (1991), "The Theory of Planned Behavior" Organisational Behavior and Human Decision Processes, 50, 179-211.

Ariff, M. S. M., Sylvester, M., Zakuan, N., Ismail, K., \& Ali, K. M. (2014). "Consumer perceived risk, attitude and online shopping behaviour; empirical evidence from Malaysia". In IOP Conference Series: Materials Science and Engineering (Vol. 58, No. 1, p. 012007). IOP Publishing.

Biswas, Dipayan ve Abhijit Biswas, (2004), "Perceived risks in online shopping: Do Signals matter more on the web?", Journal of Interactive Marketing, 18(3), 30-45.

Chen, Lei-Da ve Justin Tan, (2004), "Technology Adaptation in E-commerce: Key Determinants of Virtual Stores Acceptance", European Management Journal, 22 (1), 74-86.

Cheung, Christy M. K., Gloria W. W. Chan ve Moez Limayem (2005), "Journal of Electronic Commerce in Organizations" 3 (4), 1-19.

Claudia, I. (2012). Perceived Risk when Buying Online: Evidence from a Semi-structured Interview. Economics Series, 22(2), 63-73.

Dowling, Grahame R. ve Richard Staelin (1994), "A Model of Perceived Risk and Intended RiskHandling Activity," Journal of Consumer Research, 21, 119-34. 
Forsythe, Sandra M. ve Bo Shi, (2006), "Consumer patronage and risk perceptions in Internet shopping”, Journal of Business Research, 56 (2003), 867-875.

Forsythe, S., Liu, C., Shannon, D., ve Gardner, L. C. (2006). "Development of a scale to measure the perceived benefits and risks of online shopping." Journal of interactive marketing, 20(2), 55-75.

Gerber, Charlene \& Ward, Shannon ve Goedhals-Gerber, Leila. (2014). "The impact of perceived risk on on-line purchase behaviour." Risk Governance and Control: Financial Markets \& Institutions. 4. 99-106.

Grefen, David., Elena Karahanna ve Detmar W. Straub (2003), "Trust And TAM in Online Shopping: An Integrated Model”, MiS Quarterly, 27 (1), 51-90.

Hoffman, Donna L. ve Thomas P. Novak, (1996), “A New Marketing Paradigm for Electronic Commerce”, The Information Society An International Journal, 13 (1), 43-54.

Javadi, Mohammad Hossein Moshref, Hossein Rezaei Dolatabadi, Mojtaba Nourbakhsh, Amir Poursaeedi ve Ahmad Reza Asadollahi, (2012), "An Analysis of Factors Affecting on Online Shopping Behavior of Consumers”, International Journal of Marketing Studies, 4 (5), 81-98.

Kılıç, Sabiha ve Aykut Göksel, (2004). "Tüketici Davranışları: İndirim Kartlarının Tüketici Satın Alma Karar Süreci Üzerindeki Etkilerine Dair Ampirik Bir Çalışma.” Gazi Üniversitesi, İktisadi ve İdari Bilimler Fakültesi Dergisi, 6 (2), 147-163.

Kline, Rex B. (2005), Principles and Practice of Structural Equation Modeling, New York: The Guilford Press.

Koufaris, Marios. (2002), "Applying the Technology Acceptance Model and Flow Theory to Online Consumer Behavior”, Information Systems Research, 13 (2), 205-223.

Lewis, Michael, (2006), "The effect of shipping fees on customer acquisition, customer retention, and purchase quantities", Journal of Retailing 82 (1), 13-23.

Li, Na ve Ping Zhang, (2002), "Consumer Online Shopping Attitudes And Behavior: An Assessment Of Research", AMCIS 2002 Proceedings, 74, 508-517.

Masoud Emad Y. (2013). “The Effect of Perceived Risk on Online Shopping in Jordan”, European Journal of Business and Management, 5(6). 76-87.

Pavlou, Paul A. (2003), "Consumer Acceptance of Electronic Commerce: Integrating Trust and Risk with the Technology Acceptance Model”, International Journal of Electronic Commerce 7 (3), $101-134$

Polit, Denise F. ve Cheril Tatano Beck. (2004), Nursing Research: Principles and Methods, Philadelphia: Lippincott Publications.

Yağcı, M. İsmail ve Serap Çabuk, (2014). Pazarlama Teorileri, İstanbul: Media- Cat Yayınları.

Zhou, Lina, Dai, Livei, ve Zhang, Dongsong (2007). “Online shopping acceptance model - A critical survey of consumer factors in online shopping”, Journal of Electronic Commerce Research, 8 (1), 41-62. 